ISSN 1991-8631

Original Paper

http://indexmedicus.afro.who.int

\title{
Evaluation of efficacious activities of aqueous extract of Phyllanthus niruri against acetaminophen-induced hepatitis in rats
}

\author{
Ayuba SAMALI ${ }^{1 *}$, Florence David TARFA ${ }^{1}$, Olubukola Adebisi ODENIRAN ${ }^{1}$, \\ Cordelia Edoyi ONANUGA ${ }^{1}$ and Bulus ADZU ${ }^{2}$
}

${ }^{I}$ Department of Medicinal Chemistry and Quality Control, National Institute for Pharmaceutical Research and Development (NIPRD), Federal Ministry of Health, P.M.B. 21, Idu Industrial Area, FCT Abuja Nigeria.

${ }^{2}$ Department of Pharmacology and Toxicology, National Institute for Pharmaceutical Research and Development (NIPRD), Federal Ministry of Health, P.M.B. 21, Idu Industrial Area, FCT Abuja Nigeria.

${ }^{*}$ Corresponding author, E-mail: ayubasamali@yahoo.com, Tel: +2348069822624

\begin{abstract}
The efficacy of aqueous extract of Phyllanthus niruri against acetaminophen-induced hepatitis in rats was evaluated. The hepatic injury was induced with $200 \mathrm{mg} / \mathrm{kg}$, p.o. of acetaminophen, which led to rise in serum levels of the biochemical parameters observed. These are the aspartate aminotransferase (AST) and alanine aminotransferase (ALT) which were elevated by $22 \%$ compared to respective negative control. Treatment with the plant extract $(500,1000$ and $2000 \mathrm{mg} / \mathrm{kg}$, p.o.) lowered the biochemical parameters of the respective serum AST 31 to $38 \%$, ALT 20 to $31 \%$, Bilirubin -2 to $4 \%$, protein 5 to $15 \%$, cholesterol 0.2 to $0.5 \%$, and albumin 5 to $12 \%$. The histopathological results indicated that, the effect of the extracts on the condition of the liver as compared to the normal control ranges from mild to moderate. The biochemical variations were as a result of the different treatment involved in the study. The result therefore, shows lowering of the elevated parameters in the serum and possible reversal of hepatic cell damage with aqueous extract of Phyllanthus niruri. The trend of the study shows that, the longer the period of treatment at lower doses, the better the efficacy of the plant extract.
\end{abstract}

(c) 2012 International Formulae Group. All rights reserved.

Keywords: Phyllanthus niruri, hepatitis, acetaminophen, biochemical, histopathology, rats.

\section{INTRODUCTION}

Hepatitis disease is a major global public health problem with large number of people being infected worldwide; among which millions are chronic carriers of Hepatitis B Virus (HBV) resulting in high incidence of death per year (WHO, 2000). Many of the infected patients tend to develop cirrhosis, liver failure, or hepatocellular carcinoma (Lee, 1997; Mahoney, 1999), and liver cancer (hepatoma); a very fatal disease (Kathryn et al., 2010). The disease can be induced experimentally with carbon tetrachloride and acetaminophen (Moresco et al., 2007; Wang, 1985).

Plants have been used as a source of medicines from ancient times (Lev, 2003; Yesilada,, 2005; Alves and Rosa, 2006) and a significant portion of the currently available non-synthetic and/or semi-synthetic 
pharmaceuticals in clinical use is comprised of drugs derived from plants. A great number of these natural products came from the scientific study of remedies traditionally employed by various cultures, most of them being plant-derived (Farnsworth and Morris, 1976; Farnsworth, 1988; 1990). Studies have revealed the hepato-protective activities of different plants such as Silybum marianum, Cichorium intybus and Ficus carica Linn. (Moraceae) (Madani et al., 2008).

The plant Phyllanthus niruri (Euphorbiacea) L.-Sp. Pl. 2: 1753 [1 May 1753] (IK) (The International Plant Names Index www.ipni.org) is a small, erect, annual herb which grows $30-40 \mathrm{~cm}$ in height. It is indigenous to the rainforests of the Amazon and other tropical areas including Nigeria and is a popular herbal remedy for different ailments (Naik and Juvekar, 2003) including liver disease (Sabir and Rocha, 2008). The plant is employed for numerous conditions by the indigenous peoples as natural remedy, usually by a standard infusion or weak decoction of the whole plant or its aerial parts in water against hepatitis, and other disorders including anemia, jaundice and liver cancer.

The present study was to ascertain the anti-hepatoxic efficacy of aqueous extract of Phyllanthus niruri and also its comparison with standard amino acids, by using acetaminophen for the induction of hepatic injury in rats. The extract's phytochemical constituents, physicochemical parameters as well as safety profile $\left(\mathrm{LD}_{50}\right)$ were also evaluated.

\section{MATERIALS AND METHODS}

Sample collection and preparation

The plant sample was collected fresh from Idu, Abuja Municipal Council, FCTAbuja, Nigeria from the months of JulyAugust, 2009. It was identified by plant taxonomist at the Department of Medicinal Plant Research and Traditional Medicine, NIPRD and assigned a voucher number NIPRD No. 3649. The plant material (whole plant) was air dried and powdered; from which about $400 \mathrm{~g}$ of the powder was macerated in cold water, then filtered and evaporated over a water bath in order to obtain the extract for subsequent use.

\section{Phytochemical screening}

Prior to testing, two grams $(2.0 \mathrm{~g})$ of the plant material were rapidly extracted with $20 \mathrm{ml}$ of the solvent by shaking for 3-30 minutes or heating on water bath depending on the test in question. The solution was filtered through a whatman filter paper No.125 mm using funnel and the filtrate was used for the phytochemical test using Evans (2002) methods.

\section{Physicochemical properties}

Moisture: One grams $(1.0 \mathrm{~g})$ of the sample powdered were weighed on aluminium foil on the automated moisture analyser pan (Model MB 200, OHAUS Florham PK.USA) and set at $105{ }^{\circ} \mathrm{C}$ for 3 hours where \% moisture content of the sample was obtained (WHO, 1998).

Total ash: Two grams $(2.0 \mathrm{~g})$ of the powdered sample were ignited in a previously ignited and tarred crucible at $500{ }^{\circ} \mathrm{C}$ for about 3 hours until the sample was white, indicating the absence of carbon. It was then cooled in desiccators, weighed and the moisture content calculated as \%w/w (WHO, 1998).

\section{Determination of the extractable matter (EM)}

Four grams ( $4.0 \mathrm{~g})$ of the powdered sample were macerated with $100 \mathrm{ml}$ of distilled water by frequent shaking for 6 hours, allowed to stand for 18 hours and were then filtered; followed by evaporating $25 \mathrm{ml}$ of the filtrate in a flat bottom platinum dish on a water-bath. The extract was dried at $105{ }^{\circ} \mathrm{C}$ for about 6 hours, cooled in desiccators for 30 minutes, weighed and calculated as $\mathrm{mg}$ per gram of the powdered sample (WHO, 1998).

\section{Determination of bitterness value}

The bitterness value was determined by finding the threshold bitter concentration 
through tongue-tasting the dilutions of the quinine solutions and the plants material subsequently by different individual, beginning with the lowest concentration of the dilutions. The threshold bitter concentration at which a material continues to provoke a bitter sensation after 30 seconds was the concentration at which the bitterness was determined and calculated in units per $g$ according to WHO (1998) method using the formula: $2000 \times \mathrm{c} / \mathrm{a} \times \mathrm{b}$. Where $\mathrm{a}=$ the concentration of the stock solution $\left(\mathrm{S}_{\mathrm{T}}\right)$ $(\mathrm{mg} / \mathrm{ml})$

$\mathrm{b}=$ volume of the ST (in $\mathrm{ml}$ ) in the tube with

the threshold bitter concentration

$\mathrm{c}=$ the quantity of quinine hydrochloride R (in $\mathrm{mg}$ ) in the tube with the threshold bitter concentration.

\section{Experimental animals}

Adult Wistar rats (Six weeks old) were sourced from the Animal Facility Centre, Department of Pharmacology and Toxicology, NIPRD. They were housed in plastic cages with saw-dust as beddings and maintained at normal environmental condition. They were given food and water ad libitum. Their usage was in accordance with NIH Guide for the Care and Use of Laboratory Animals (NIH Publication No. 83-27, 1985).

\section{Acute toxicity test}

The oral acute toxicity test was carried out in healthy adult Wistar rats (140-200 g) according to Lorke's method (1983). Briefly, the rats were divided into four groups and treated orally with the extracts of the plant at doses of $1000-8000 \mathrm{mg} / \mathrm{kg}$, p.o. They were observed for sign of toxicity in the first six hours and mortality within $24 \mathrm{~h}$ was monitored. The $\mathrm{LD}_{50}$ was estimated from the square root of the lowest lethal dose and the highest non-lethal dose (Vongtau et al., 2004).

\section{Treatment protocol}

Thirty-five adult rats of both sexes of weights ranging from 140-200 $\mathrm{g}$ were used for the study. The animals were housed in iron cages in well ventilated standard animal house and fed with standard animal feed and water throughout the period of the study. The animals were divided equally into eight groups $(\mathrm{n}=5)$ as follows:

Group 1: Served as control group

Group 2: $200 \mathrm{mg} / \mathrm{kg}$ of acetaminophen (Dennis, 2011)

Group 3: $200 \mathrm{mg}$ acetaminophen /500 mg plant extract

Group 4: $200 \mathrm{mg}$ acetaminophen /1000 mg plant extract

Group 5: $200 \mathrm{mg}$ acetaminophen /2000 mg plant extract

Group 6: $200 \mathrm{mg}$ acetaminophen $/ 950 \mathrm{mg}$ cysteine (Wang et al., 1985).

Group 7: $200 \mathrm{mg}$ acetaminophen /300 mg phenyl alanine

After the seven days exposure to treatment, the rats were sacrificed by decapitation and the blood was collected using syringe, allowed do clot, centrifuged at room temperature and the serum was stored in tubes for subsequent biochemical parameter analysis (Schmdt, 1993).

\section{Biochemical parameter assessment}

The following parameters were assessed: aspartate aminotransferase (AST), alanine aminotransferase (ALT), total bilirubin, total protein, albumin, cholesterol, using standard kits for activity as indicators of liver function and generalized tissue damage respectively by using appropriate methods (Nagini and Selvam, 1997; Jin et al., 2007).

\section{Histopathological assessment}

After blood was collected, the liver was fixed in $10 \%$ neutral formalin for at least 24 hrs, dehydrated in graded $(50-100 \%)$ alcohols, embedded in paraffin, cut into $4-5$ $\mu \mathrm{m}$ thick sections and stained with haematoxylin-eosin. It was then examined under photomicroscope (Ezeonwumelu et al., 2011) for characterization of histopathological changes in the tissues by a histopathologist in blind fashion (Alan et al., 2002; Jin et al., 2007). 


\section{Statistical analysis}

Data collected were processed by using Microsoft excel, summarized as mean \pm SD, and interpreted in form of histogram.

\section{RESULTS}

The phytochemical screening of the extract shows the presence of alkaloids, balsam, carbohydrate, flavonoids, saponins, resins, tannins, phlobatannins, steroids, glycosides and traces of terpenoids. The extract's physicochemical parameters are presented in Table 1. The $\mathrm{LD}_{50}$ of the extract was above $5000 \mathrm{mg} / \mathrm{kg}$, p.o., indicating that the experimental doses used were within the safe margin.

Biochemical parameters, AST, ALT, total bilirubin, total protein; triglyceride, creatinine, cholesterol, and albumin are presented in Figures $1-6$; while the histopathological conditions of the liver for the different treatment groups are presented in Table 2.

The conditions of the representative samples of the liver of the rats are presented in form of slides A, B, C and D. Slide A shows the liver condition of normal control group showing normal hepatic cells, B shows the acetaminophen-induced group which indicated extensive injury with extensive portal fibrosis, while $\mathrm{C}$ indicated that $500 \mathrm{mg}$ of the extract administered led to portal moderate condition showing mild portal fibrosis, and D shows liver section of showing mild condition.

Table 1: Physicochemical parameters.

\begin{tabular}{lcccc}
\hline Parameters & $\begin{array}{c}\text { Loss on drying } \\
(\% \text { w/w })\end{array}$ & $\begin{array}{c}\text { Total ash } \\
(\% \text { w/w })\end{array}$ & $\begin{array}{c}\text { Bitterness } \\
\text { value } \\
(\text { Units/g })\end{array}$ & $\begin{array}{c}\text { Water } \\
\text { extractable } \\
(\% \mathbf{w} / \mathbf{v})\end{array}$ \\
\hline Value & $12.4057 \pm 0.45$ & $6.9950 \pm 0.46$ & $1636.88 \pm 0.74$ & $1.3353 \pm 0.10$ \\
\hline
\end{tabular}

Table 2: Histopathological conditions of the liver.

\begin{tabular}{|c|c|c|c|c|c|c|c|}
\hline Treatment & $\begin{array}{l}\text { Normal } \\
\text { control }\end{array}$ & $\begin{array}{l}200 \mathrm{mg} \\
\text { Aceta. }\end{array}$ & $\begin{array}{l}500 \mathrm{mg} \\
\text { extract }\end{array}$ & $\begin{array}{c}1000 \mathrm{mg} \\
\text { extract }\end{array}$ & $\begin{array}{c}2000 \mathrm{mg} \\
\text { extract }\end{array}$ & $\begin{array}{l}950 \mathrm{mg} \\
\text { cysteine }\end{array}$ & $\begin{array}{l}300 \mathrm{mg} \\
\text { Phenyl- } \\
\text { alanine }\end{array}$ \\
\hline Effect & $\begin{array}{c}\text { normal } \\
\text { cells }\end{array}$ & $\begin{array}{l}\text { extensive } \\
\text { portal } \\
\text { inflam- } \\
\text { matory }\end{array}$ & $\begin{array}{c}\text { mild } \\
\text { cell } \\
\text { injury }\end{array}$ & $\begin{array}{l}\text { moderate } \\
\text { inter- } \\
\text { tubular, } \\
\text { interphase } \\
\text { tract } \\
\text { inflam- } \\
\text { mation }\end{array}$ & $\begin{array}{l}\text { moderate } \\
\text { inter- } \\
\text { tubular, } \\
\text { interphase } \\
\text { tract } \\
\text { inflam- } \\
\text { mation }\end{array}$ & $\begin{array}{c}\text { moderate } \\
\text { inter-tubular, } \\
\text { interphase } \\
\text { tract } \\
\text { inflammation }\end{array}$ & $\begin{array}{c}\text { extensive } \\
\text { portal } \\
\text { inflammation }\end{array}$ \\
\hline
\end{tabular}




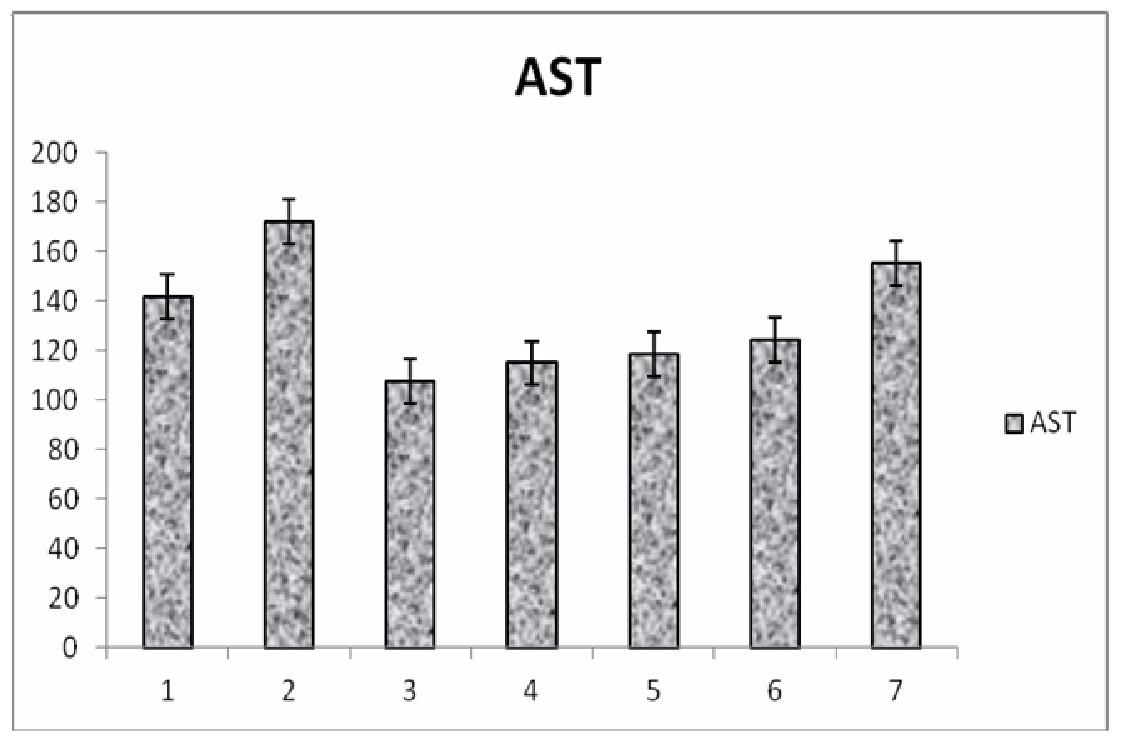

Figure 1: Average level of AST among the treatment groups.

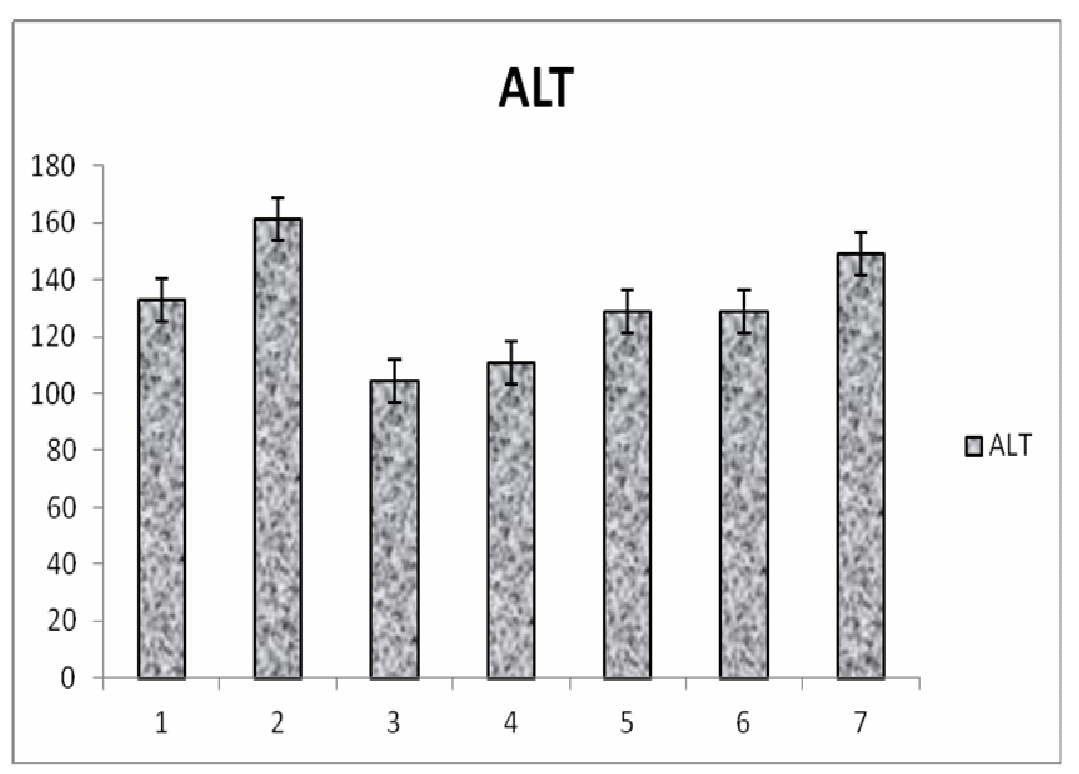

Figure 2: Average level of ALT among the groups. 


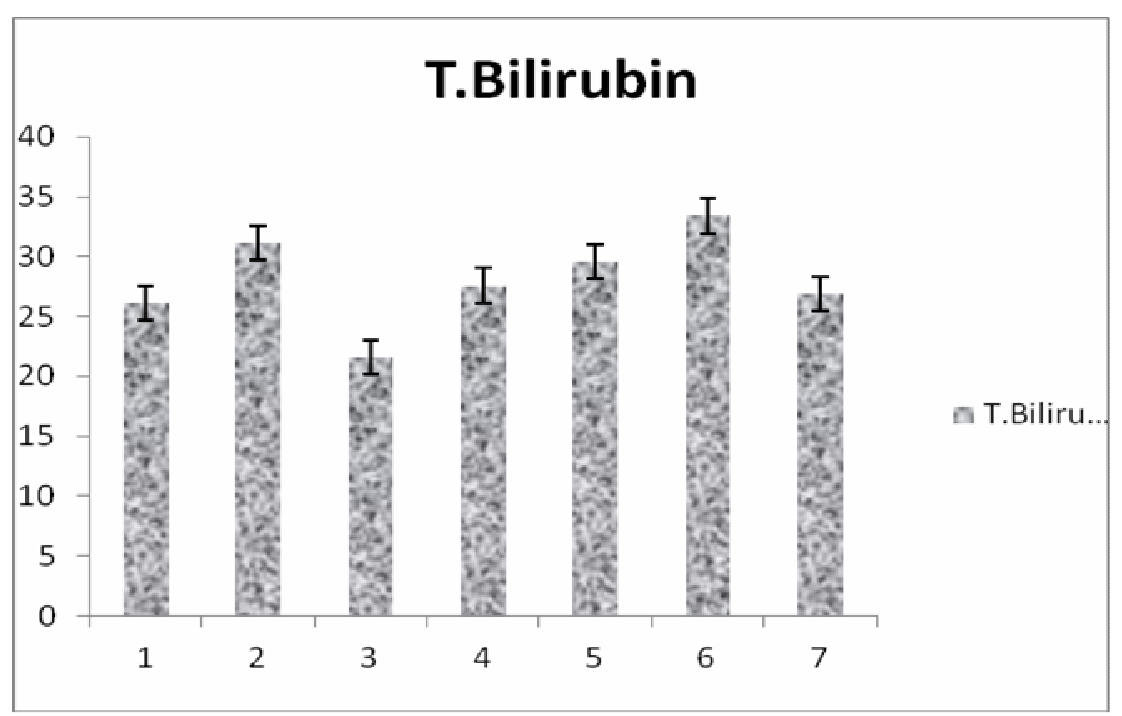

Figure 3: Average level of total bilirubin among the groups.

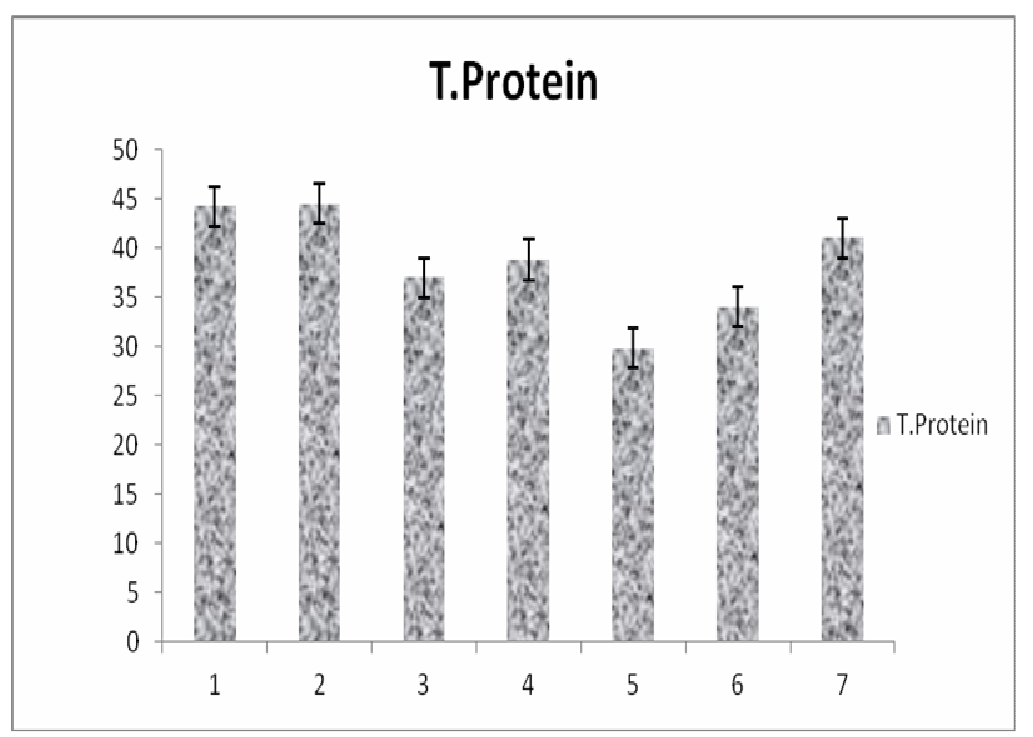

Figure 4: Average level of total protein among the groups. 


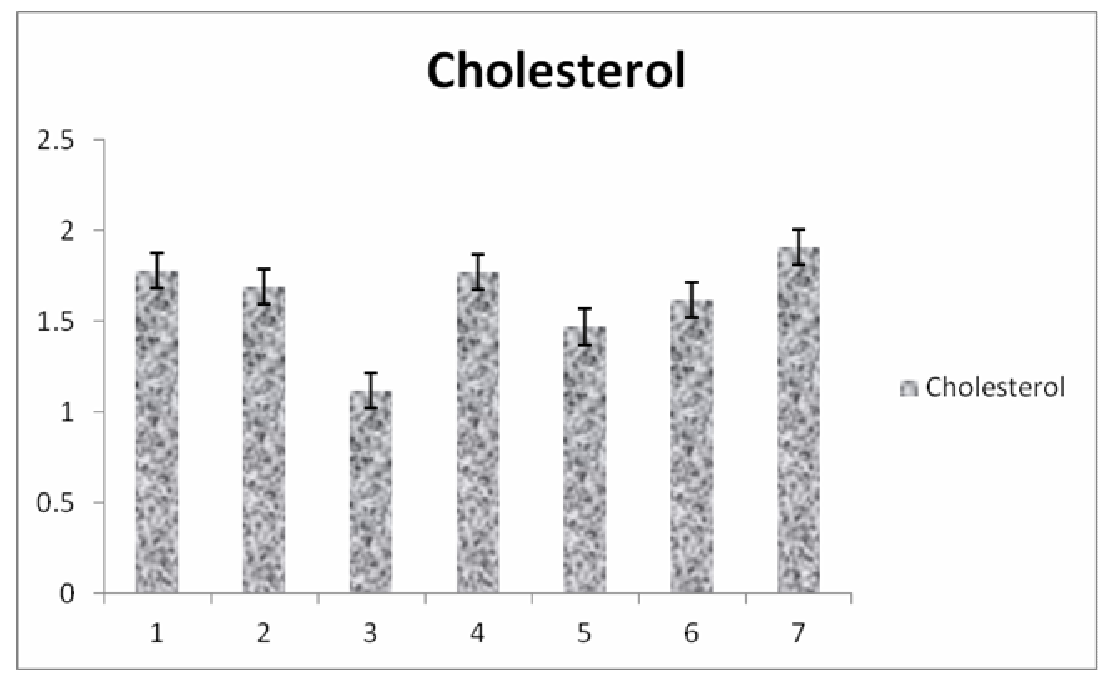

Figure 5: Average level of cholesterol among the groups.

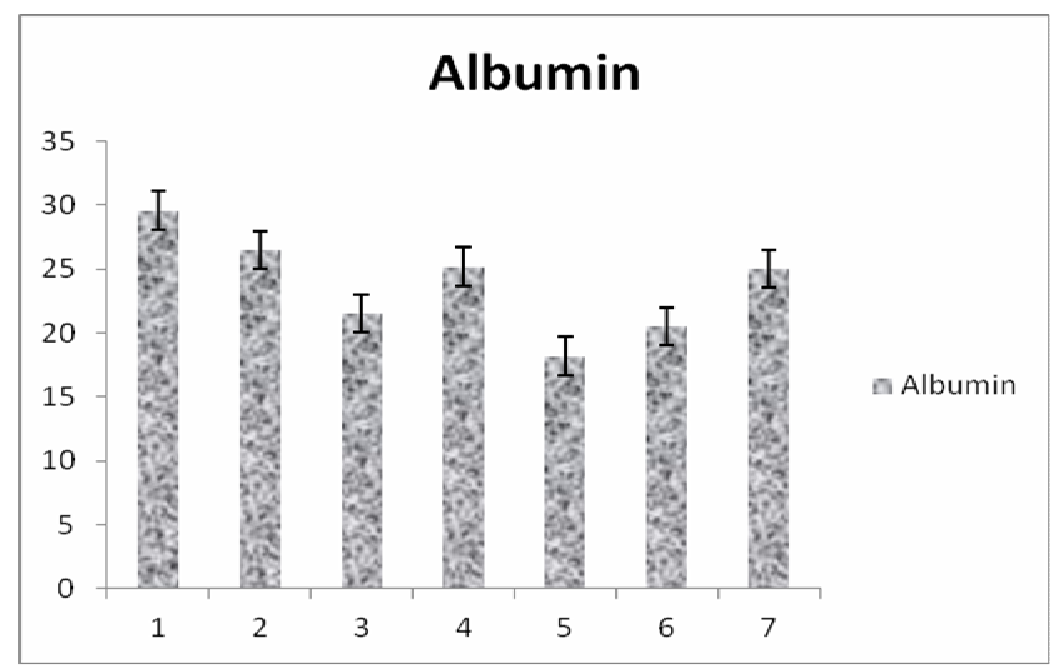

Figure 6: Average level of albumin among the groups.

Figures $1-6$ are the histograms of the biochemical parameters (AST, ALT, total bilirubin, total protein, creatinine, triglyceride, cholesterol and albumin) respectively. These were chosen as the indicators to any changes in the condition of the liver which may result due to the inducement with the acetaminophen overdosed and the various treatments involved. 


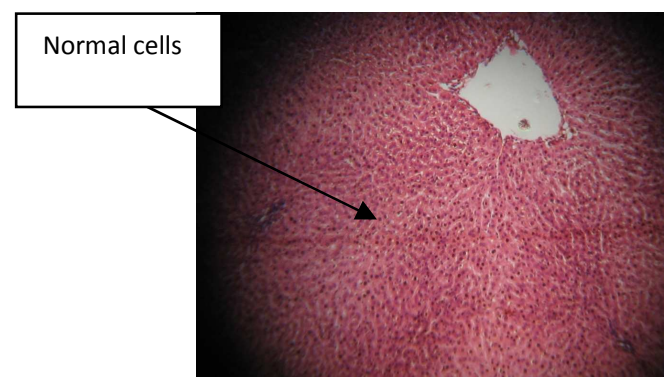

A. Liver section of typical normal hepatic cells

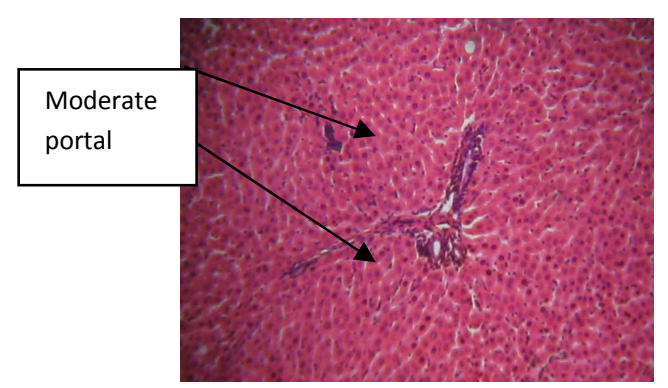

C. Section of liver of moderate condition. D. Liver section showing mild condition

B. Liver section showing extensive portal fibrosis
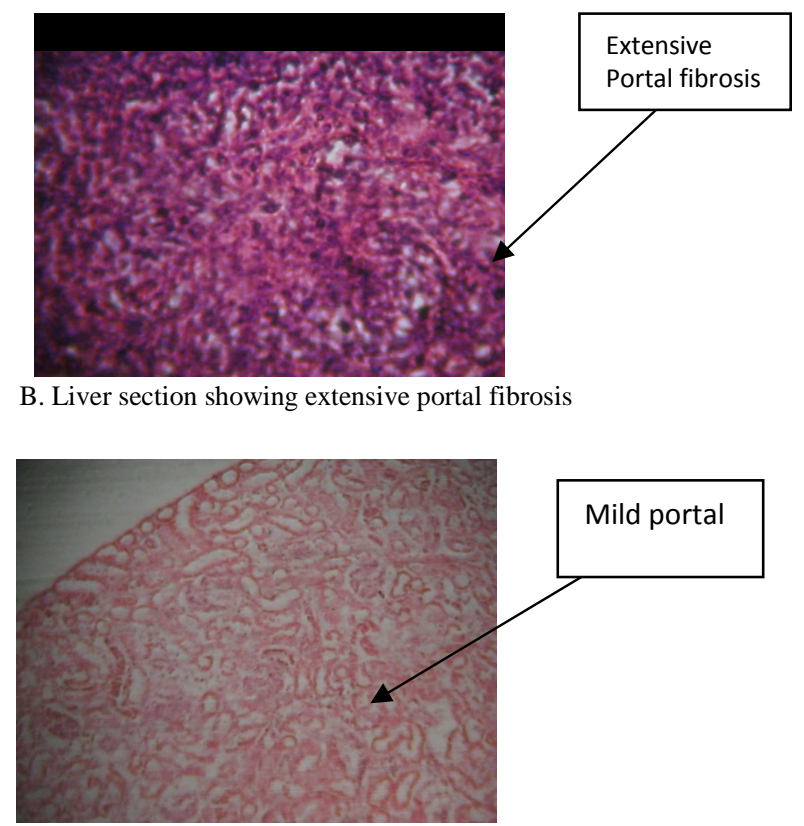

Figure 7: Hepatic cells (haematoxylin-eosin stain) sections of liver of various conditions observed. (200 mg p.o); C, typical for extract groups (1000 mg, $2000 \mathrm{mg}$ ) and positive control group (950 mg cysteine/ $300 \mathrm{mg}$ phenyl alanine); and $\mathrm{D}$ for $500 \mathrm{mg}$ of the extract .

\section{DISCUSSION}

The phytochemical result indicated that aqueous extract of Phyllanthus niruri is rich in phytochemicals that are known to have effect on different form of diseases. Physicochemical parameters play a vital role in relating the properties of the plant and its activities; total ash is means of gauging elemental content. Water extractable matter is use as the quantitative variable by which physiological projection can be tested. The result obtained indicated that $1 \mathrm{~g}$ of the extract is equivalent to $13 \mathrm{mg}$ of the water extractable matter. The bitterness value serves as a marker for bioactive ingredient (pharmacological parameters) of plants (Balick, 1990; Ameh et al., 2009). The $\mathrm{LD}_{50}$ of the extract was above $5000 \mathrm{mg} / \mathrm{kg}$, p.o., indicating that the experimental doses used were within the safe margin.

Biochemical enzymes monitored during the study indicated elevated AST,
ALT, total bilirubin and total protein, which remained high throughout the period of the study in the acetaminophen induced group that wasn't treated, while those of the treated groups are low as shown in Figures 1, 2 and 3. The percentage activities of the extracts on these elevated enzymes as compared to the normal group were as follows; AST 31 to $38 \%$, ALT 20 to $31 \%$, Bilirubin -2 to $4 \%$. From literature, leading factors to rise in bilirubin level are due to cirrhosis, hepatitis or Gilbert's diseases (Berk and Korenblat, 2007; Prat, 2010). In this study, $500 \mathrm{mg}$ of the plant extracts (Figure 3) gave a better activity in protecting the liver.

The total protein test measures the total amount of two classes of proteins found in the fluid portion of blood; albumin and globulin. Albumin helps preventing fluid from leaking out of blood vessels, while globulins are an important part of your immune system. Higher-than-normal level protein in the blood 
are due to chronic inflammation or infection, including HIV and hepatitis B or C; while lower-than-normal levels are due to bleeding (hemorrhage), liver disease or other related diseases (Tricot, 2005). In this study, the total protein lowered by the extracts treatment groups' ranged from 5 to $15 \%$ as shows in Figure 4, indicating that the higher dose (2000mg/kg, p.o.) has better activity than the positive control (cysteine).

High cholesterol level lead to clogging of arteries and thus contributing to heart diseases (Berk and Korenblat, 2007, Prat, 2010) In this study, the extracts lowered the elevated cholesterol level than the negative control group by 0.2 to $0.5 \%$ (Figure 5). Low than normal level of albumin as a blood protein; elevate bilirubin levels, clotting problems or other abnormalities which can point towards liver disease for example, hepatitis, cirrhosis, orascite (Berk and Korenblat, 2007, Prat, 2010). The results from the study indicated that $500 \mathrm{mg}$ and 2000 $\mathrm{mg} / \mathrm{kg}$, p.o. of the extract exhibited good activities compared to the normal control group by 5 to $12 \%$ (Figure 6).

The findings from this study indicated that chemical potentials of the aqueous extract of Phyllanthus niruri had played vital roles which led to significant changes on the biochemical parameters observed as indicators to changes in condition of organs such as liver by inducement with acetaminophen.

Representative slides of the histopathological condition of the liver, presented as slide A, B, C and D shows condition ranges from mild, moderate to extensive portal tract inflammation with sign of focal necrosis. The cells show moderate, inter-tubular, inter-phase tract inflammation to extensive necrosis. Treatment with the extracts (groups 3, 4 and 5) showed inhibition of these conditions by the extract within the period of the treatment this corresponding to with the biochemical enzymes of the liver. The positive control groups which involved treatment with standard amino acids indicated the condition of the liver cells as, moderate to extensive portal inflammation with focal areas of necrosis as summarized in Table 2, while the hepatotoxicity induced by acetaminophen showed significant developments of inflammated lumps on the liver of some of the rats of the different treatment groups.

These results thus indicates that, Phyllanthus niruri extract has hepatoprotective activities against hepatitis diseases and other liver related problems (Naik and Juvekar., 2003) at the dose of 500 $\mathrm{mg}$; the activities of the extract inhibited properties similar to the standard enzymes used (Wang et al., 1985). In conclusion, the present study proved the antihepatotoxicity of the aqueous extract of Phyllanthus niruri with significant changes both within and between the treatment groups by seven (7) days, due to different treatments and doses administered to the rats. There is therefore, the need to further investigate the plant in order to isolate the active phytochemical constituents responsible for the observed effect with the view to develop it for the treatments of liver and related diseases.

\section{ACKNOWLEDGEMENTS}

The research was funded by the authors. The authors thank Mr. Sunday Dzarma of Animal Facility Center, NIPRD for handling the animals during the study, Mr. Markus Kato and Mustapha Bakare of Teaching Hospital Gwagwalada for carryingout the histopathological and the biochemical parameter assessment, respectively. Collectively we appreciate NIPRD for giving us atmosphere for carrying-out this work.

\section{REFERENCES}

Alan S, James SL, Barbara Y. 2002. Wheater's Basic Histopathology ( $4^{\text {th }}$ edn). A colour Atlas and Text: Churchill Living Stone; 1-12.

Alves RRN, Rosa IL. 2006. From cnidarians to mammals: The use of animals as remedies in fishing communities in NE Brazil. J. Ethnopharmacol., 107: 259-276. 
Ameh SJ, Obodozie OO, Afolabi EK, Oyedel $\mathrm{EO}$, Ache TA, Onanuga $\mathrm{CE}$, Ibe $\mathrm{MC}$, Inyang US. 2009. Some basic requirements for preparing an antisickling herbal medicine-NIPRISAN. Afr. $J$. Pharmacy Pharmacol., 3(5): 259-264.

Balick MJ. 1990. Ethnobotany and the identification of therapeutic agents from the rainforest. In Bioactive Compounds from Plants. Edited by: Anonymous. Ciba Foundation Symposium 154. Wiley Interscience: New York; 22-31.

Berk PD, Korenblat KM . 2007. Approach to the patient with jaundice or abnormal liver test results. In Cecil Medicine (23 ${ }^{\text {rd }}$ edn), Goldman L, Ausiello D (eds). Saunders Elsevier: Philadelphia, Pa; 150.

Dennis L. 2011. Tylenol (Acetaminophen) Liver Dammage: MedicineNet.com.

Evans WC. 2002. Trease and Evans Pharmacognosy. (15 $5^{\text {th }}$ edn). Saunders: Edinburgh; 249-454.

Ezeonwumelu JOC, Julius AK, Muhoho CN, Ajayi AM, Oyewale AA, Tanayen JK, Balogun SO, Ibrahim A, Adzu B, Adiukwu CP, Oloro J, Kiplagat DM, Goji ADT, Okoruwa AG , Onchweri AN, Reddy PMK. 2011. Biochemical and histological studies of aqueous extract of Bidens pilosa leaves from Ugandan Rift Valley in rats. Brit. J. Pharmacol. Toxicol., 2(6): 302-309.

Farnsworth NR, Morris RW. 1976. Higher plants: the sleeping giant for drug development. Am. J. Pharm., 148: 46-52

Farnsworth NR. 1988. Screening plants for new medicines. In Biodiversity, Wilson EO. Washington DC (eds): National Academy Press; 83-97.

Farnsworth NR. 1990. The role of ethnopharmacology in drug development. In Bioactive Compounds from Plants. Ciba Foundation Symposium 154. Wiley Interscience: New York; 2-11.

Jin Y-S, Kim M-K, Heo S, Han W, Wang MH. 2007. Indentification and properties of 2,5-Dihydroxy-4,3-di (B-D-glucopyranosyloxy)-trans-stilbene from Morus bombycis Koidzumi root. Phytother. Res., 21(7): 605-608.

Kathryn LN, Tracy W, Ashley SM, Brown Susan ED, Graeme JMA. 2010. Hepatocellular carcinoma in patients with chronic hepatitis $\mathrm{C}$ virus infection without cirrhosis. World J. Gastroenterol., 16(32): 4061-4065.

Khashab M, Tector AJ, Kwo PY. 2007. Epidemiology of acute liver failure. Curr Gastroenterol. Rep. 9(1): 66-73.

Lev E. 2003. Traditional healing with animals (zootherapy): medieval to present-day Levantine practice. J. Ethnopharmacol., 86: 107-118.

Lorke D. 1983. A New Approach to Practical Acute Toxicity Testing. Archiv. Toxicol. 54: 275-287.

Lee WM. 1997. Hepatitis B Virus infection: a review. N. Engl. J. Med., 324: 1733-1745.

Madani H, Talebolhosseini M, Asgary S, Nader GH. 2008. Hepatoprotective activity of Silybum marianum and Cichorium intybus against thioacetamide in rat. Pak J. Nutri., 7(1): 172-176.

Mahoney FJ. 1999. Update on diagnosis, management, and prevention of hepatitis B virus infection. Clin. Microbiol. Rev., 12: 351-366.

Moresco RN, Sperotto RL, Barnardi AS, Cardoso RF, Gomes P. 2007. Effect of the aqueous extract of Syzygium cumini on carbon tetrachloride-induced hepatotoxicity in rats. J. Phytochemical. research. 21(8): 795-791.

Nagini SS, Selvam. 1997. Biochemical indicators of membrane damage in the plasma and erythrocytes of rats fed the peroxisome proliferation di (2-ethylhexyl) phthalate, Medical Scie. Res., 25: 119-121.

Naik AD, Juvekar AR. 2003. Effects of alkaloidal extract of Phyllanthus niruri on HIV replication. Indian J. Med Sci., 57: 387.

Pratt DS. 2010. Liver chemistry and function tests. In Sleisenger and Fordtran's Gastrointestinal and Liver Disease. $\left(9^{\text {th }}\right.$ 
edn). Feldman M, Friedman LS, Brandt LJ (eds). Saunders Elsevier: Philadelphia, $\mathrm{Pa}$; 73.

Sabir SM, Rocha JBT. 2008. Waterextractable phytochemical from Phyllanthus Niruri exhibit distinct in vitro antioxidant and in vivo hepatoprotective activity against paracetamol-induced liver damage in mice. J. Food Chem., 4: 60.

Schmidt R. 1993. Laboratory Diagnosis of hemoglobinopathies: In Hematology Clinical and Laboratory Practice $\left(1^{\text {st }}\right.$ edn), Brick L (ed). USA, Mosby; 327371.

Tricot G. 2005. Multiple myeloma and other Plasma Cell Disorder. Hematology. In Basic Principles and Practice (4 ${ }^{\text {th }}$ edn). Hoffman R, Benz EJ Jr, Shattil S, Furie B, Cohen H, Siberstein L, McGlave P (eds). Elsevier Inc.; 1501-1535.

Vongtau HO, Abbah J, Mosugu O, Chindo BA, Ngazal IE, Salawu AO, Kwanashie
HO, Gamaniel KS. 2004. Antinociceptive profile of the methanolic extract of Neorautanania mitis root in rats and mice. J. Ethnopharmacol., 92: 317-324.

Wang D, Verney E, Sidransky H. 1985. Protective effect of tryptophan and cysteine against carbon Tetrachlorideinduced liver injury. Exp. Mol. Pathol., 43(3): 364-374.

World Health Organization. 2000. Hepatitis B. World Health Organization Fact Sheet 204 http://who.int/inf-fs/en/fact204.htm

World Health Organization. 1998. Quality Control Methods for Medicinal Plant Materials. WHO: Geneva Switzerland; 115.

Yesilada E. 2005. Past and future contributions to traditional medicine in the health care system of the Middle-East. J. Ethnopharmacol., 100: 135-137. 